\title{
宿主エネルギー代謝制御における腸内細菌と 遊離脂肪酸の役割
}

\section{Fatty Acid Metabolism and Gut Microbiota in Host Homeostasis}

\author{
向山 広美 \\ 東京農工大学 大学院農学研究院 \\ 応用生命化学専攻 \\ T 183-8509 \\ 東京都府中市幸町 3-5-8 \\ Hiromi MUKOUYAMA \\ Department of Applied Biological \\ Science, Graduate School of \\ Agriculture, Tokyo University of \\ Agriculture and Technology
}
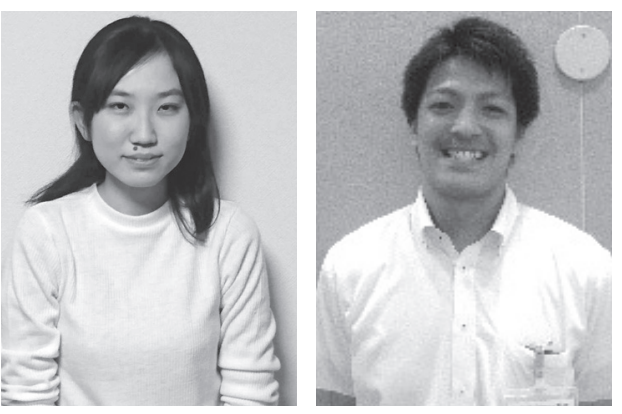

論文要旨：我々は生命を維持するために食事によるエネルギー摂取が非常に重要である。しかしながら, 近年，食の欧米化に伴い，過度な食事や高脂肪・高炭水化物食（高エネルギー食）による過剩エネルギー摂 取が，生活習慣病などのエネルギー代謝異常疾患を引き起こすことが問題となっている。また，近年の研究 で，腸内細菌叢がエネルギー代謝異常疾患と密接に関与することが科学的根拠に基づき明らかにされた。さ らに，その分子実体の一つとして腸内細菌代謝物に注目が集まり，宿主のエネルギー代謝や免疫機能だけに 留まらず，各種末梢臓器を介した恒常性維持に密接に影響することが科学的根拠に基づいて明らかにされ始 めた。そこで, 本稿では, 食事と腸内細菌の関与, 及びその代謝物による宿主生体恒常性維持に及ぼす影響 について，我々の知見と，最近の研究状況とともに概説する。

\begin{abstract}
In the past decades, many studies are reported that gut microbiota have not only to form the community in the gut but also to have a pivotal role in the human health. Especially, the alteration of gut microbiota (dysbiosis) have risk factors for human diseases, therefore, the gut microbiota has become a focus for research at the interaction between diet (key factor) and metabolic health. To date, accumulated extensive body of scientific knowledge is exhibited to the gut microbiota as a mediator of dietary impact on the host metabolism. This review will discuss the recent studies in underlying mechanisms whereby the gut microbiota modulates the effects of diet and shapes the host metabolism either towards or away from obesity and related metabolic conditions. In addition, to discuss the recent studies in relation to gut microbial metabolite of dietary lipids and host energy regulation, and evaluate for potential as novel therapeutic targets for diet-induced obesity and related metabolic disorders.
\end{abstract}

Key words: gut microbiota, microbial metabolite, dietary lipid, energy homeostasis, FFAR

\section{1 はじめに}

近年のオミクス解析の発展と腸内細菌学の確立によっ て, 腸内環境の変化が宿主の生体恒常性維持と密接に関 与することが科学的根拠に基づいて明らかにされ始め た。我々の消化管内には重さにして $1.5 \mathrm{~kg}$, 数にして $10^{14}$ 個以上もの腸内細菌が棲息し，一つのコミュニ ティーを形成しており, エネルギー代謝異常疾患, 免疫 疾患や神経系疾患など腸管関連疾患から末梢組織におけ

連絡者：宮本 潤基

E-mail : m-junki@go.tuat.ac.jp
る疾患まで，ある種の腸内細菌が様々な病態と密接に関 与することが示唆されている ${ }^{1)}$ 。一方, このような腸内 細菌と宿主を結びゔける実質的な分子実体として，腸内 細菌由来代謝物が注目され始め, 生体恒常性維持に重要 な役割を果たしていることが示唆されてきた。近年では, 我々が摂取した食事を利用して産生される新規の腸内細 菌代謝物（食由来腸内細菌代謝物）の存在も確認されて おり, 宿主の生体恒常性維持に寄与する重要な分子実体 としての食由来腸内細菌代謝物研究に注目が集まりつつ ある。そこで, 本稿では, 食由来腸内細菌代謝物が宿主 の生体恒常性維持に及ぼす影響について, 我々の最新の 
知見と共に概説する。

\section{2 腸内環境とエネルギー代謝制御}

腸内細菌叢が宿主のエネルギー代謝・恒常性維持に深 く関与すると考えられるようになり，エネルギー代謝異 常疾患などの病態に直接的に影響することが証明されつ つある。最たる例として, 2006 年に米国ワシントン大 学のゴードンらの研究グループは, 腸内細菌叢のバラン スとエネルギー代謝異常疾患の発症が密接に関与するこ とを, 無菌マウスを用いた研究によって報告した ${ }^{2,3)}$ (Fig. 1)。それ以降，彼らの研究グループを中心に，腸内細 菌叢とエネルギー代謝制御に関する研究が数多く報告さ れ始めた ${ }^{4)}$ 。また，ヨーロッパと中国における 2 型糖尿 病患者のコホート研究の結果, 全ての 2 型糖尿病患者の 腸内細菌叢において酪酸産生クロストリジウム属の割合 が低く，一方で非酪酸産生クロストリジウム属の割合は 高い事が明らかとなった ${ }^{5,6)}$ 。しかしながら，変化した 腸内細菌の細分化した分類に，ヨーロッパと中国で必ず しも統一性が認められず，これらの結果は人種や食生活 が腸内細菌叢に影響を及ぼしていることを示唆してい る。

腸内細菌は菌体自身も非常にユニークな物質を細胞表 面などに有しており，様々なシグナル応答を介すること で宿主との共生関係を維持している。例えば，宿主側の Toll 様受容体（TLRs）は腸内細菌の細胞壁構成成分な どを認識することで宿主の炎症や免疫を介するパターン 認識受容体として機能すると同時に，エネルギー代謝に も寄与することが示唆されている。腸内細菌の持つ鞭毛 の一種である Flagellin は TLR5 のリガンドとして知ら れているが, このTLR5 を欠損したマウスは過食を呈し,

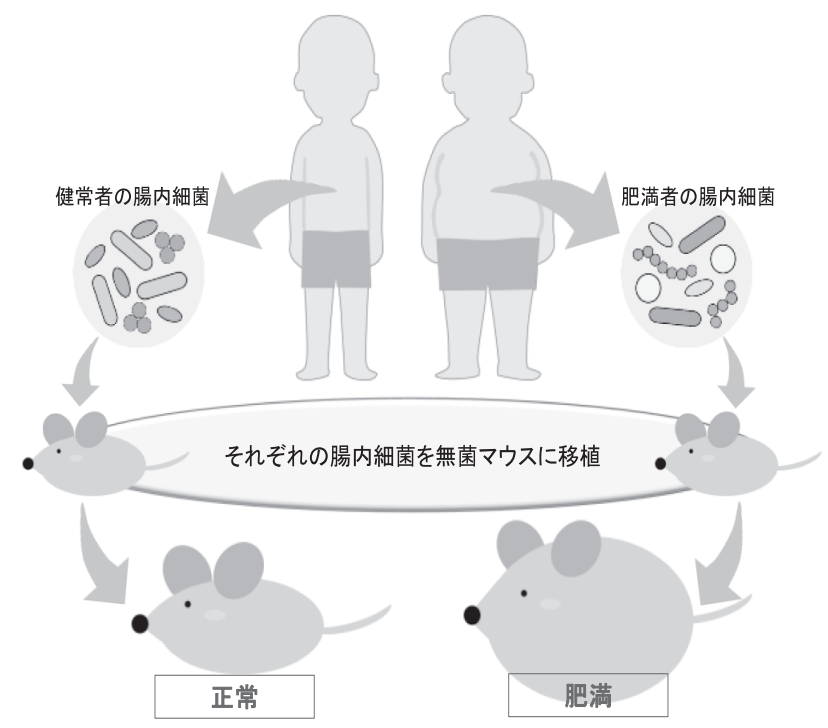

Fig. 1 腸内細菌叢と肥満
肥満やインスリン抵抗性を発症することが報告された ${ }^{7)}$ 。 また, この Tlr5 欠損マウスの腸内細菌叢を移植したマ ウスは, Tlr5 欠損マウスと同様に肥満を発症すること から, TLR5 シグナルが腸内細菌叢組成の変化に重要な 役割を果たしており，その結果，宿主のエネルギー代謝 に寄与することが示唆された。さらに, 興味深いことに, 新生児期における宿主の腸管上皮細胞の TLR5を介し た Reg3 $\gamma$ 産生が, 腸内細菌叢の定着に強力に関与する ことが明らかにされた ${ }^{8)}$ 。すなわち，成体期における有 用な腸内細菌叢は, 新生児期に決定され，成体期におけ る宿主生体恒常性維持と密接に関与することが示唆され た。最近では, 腸内細菌の一種でVerrucomicrobia 門 に属するAkkermansia muciniphila が, 肥満マウスや糖 尿病マウスにおいてはその割合が減少していることが報 告されている ${ }^{9)}$ 。また, エネルギー代謝異常マウスに $A$. muciniphila を投与すると, 腸粘膜バリアの増強と代謝 改善作用が示され，その分子メカニズムの一端として， A. muciniphilaの細胞壁外膜タンパク質 Amuc_1100が Toll 様受容体の一つである TLR2 を介したものである ことも明らかにされている ${ }^{10)}$ 。さらに，加齢によって 引き起こされるインスリン抵抗性などの病態に対して も, A. muciniphilaの関与が示唆されており ${ }^{11)}$, 今後, エネルギー代謝異常疾患に対するA. muciniphilaのよ り詳細な関係性の解明が期待される。

一方, オミクス解析の進歩に伴い, 腸内細菌叢の変化 に起因した代謝産物にも注目が集まりつつある。例えば, 肥満患者と健常者の血中メタボローム解析により, 分岐 鎖アミノ酸 (BCAA; branched chain amino acids) が 肥満患者で高值であることが見出され，BCAA 含有高 脂肪食をマウスに与えると，インスリン抵抗性を発症す ることも観察された ${ }^{12)}$ 。さらに，コペンハーゲン大学 のペデルセンらは，肥満患者で BCAA 合成酵素を有す る腸内細菌種 (Prevotella copri と Bacteroides vulgatus) の酵素活性が顕著に立進していることを明らかにし，高 脂肪食負荷マウスにP. copriを投与すると, 血清 BCAA レベルの上昇に伴い，インスリン抵抗性の誘導や 耐糖能障害の悪化が観察されることを明らかにした ${ }^{13)}$ 。 このことは, 腸内細菌叢のバランス異常により誘導され る血清メ夕ボロームの変化が, エネルギー代謝異常疾患 の発症と密接に関与していることを示唆している。一方, 興味深いことに，高食物繊維・低脂肪食を与えたマウス においては，P.copriが糖代謝改善と正の相関を示すこ とも報告されている ${ }^{14)}$ 。また，最近では，炎症性マク ロファージなどに発現するインドールアミン 2,3- ジオキ シゲナーゼが肥満時にはトリプトファン代謝を立進する ことでインスリン抵抗性の発症に関与することが示され 
たが，インドールアミン 2,3- ジオキシゲナーゼの阻害は, 腸内環境の調節を介してインスリン感受性を立進し, 肝臓 や脂肪組織での脂質代謝を改善することが示唆された ${ }^{15)}$ 。 さらに, 2 型糖尿病患者に特徵的な腸内細菌である Streptococcus mutans や Eggerthella lenta はヒスチジン からのイミダゾール・プロピオン酸（代謝中間体）産生 に関与しており，実際に 2 型糖尿病患者ではイミダゾー ル・プロピオン酸が高值を示し，健常マウスに投与する とインスリン抵抗性が惹起されることも示されている ${ }^{16)}$ このように, 我々と共生関係にある腸内細菌叢は, 様々 な代謝経路によって，宿主の生体恒常性に影響を及ぼす ことが示唆された。

このように，様々な病態と密接に関連することが示唆 され始めている腸内細菌叢は, 食事, 抗生物質やストレ スなどの外来因子によっても劇的にその構成が影響を受 けることもよく知られている。例えば，抗生物質は生体 外から侵入した病原菌に対処する目的で処方されるが, 服用することで生体内に常在する腸内細菌にも大きな影 響を及ぼす。その一例として, 肥満患者にバンコマイシ ン（グリコペプチド系抗生物質）を投与すると, Firmicutes 門に属する菌の減少と，インスリン感受性の低 下が観察される。一方，アモキリシン（ペニシリン系抗 生物質）による同様の検討ではインスリン感受性に変化 は観察されなかったことから, Firmicutes 門は肥満時 における宿主のインスリン感受性に影響を及ぼす可能性 が示唆された ${ }^{17)}$ 。しかしながら, 生後 4 週齢（離乳直後） のマウスに低用量の抗生物質を投与し, 腸内細菌叢組成 と機能の変化を調べたところ, 約 6 週間後において, 抗 生物質を投与されたマウスでは, 非投与群のマウスと比 較して, 体重および脂肪重量の増加が確認された。イン クレチンの一つである GIP などの腸管ホルモン濃度が 高く, 腸内細菌叢組成は投与群において有意な Firmicutes 門の増加も明らかとなった ${ }^{18)}$ 。また, 抗生物質 の投与により，腸内細菌代謝物である短鎖脂肪酸や二次 胆汁酸が劇的に減少することで, 細胞内代謝がグルコー ス利用に偏ったことで，GIP と同様に GLP-1の劇的な 増加が誘発されることで, 糖代謝異常を来すことも報告 されている ${ }^{19)}$ 。さらに，近年では，妊娠期から授乳期 までの抗生物質の投与が，胎児の攻撃性を克進すること も報告されており ${ }^{20)}$, 今後, 妊娠中の母親の抗生物質 投与や乳幼児に対する抗生物質投与に関して, 慎重に治 療方針を見極めていく必要があると考えられる。このよ うに, 抗生物質などの外来因子は腸内細菌叢の構成を劇 的に変化させることで，宿主の恒常性維持に影響を及ぼ すことが示唆されているが, 我々が生命を維持するため に必須な食事も腸内細菌叢へ影響を及ぼすことが知られ
ている。

\section{3 腸内細菌と食事脂質・脂肪酸代謝}

様々な病態と密接に関連することが示唆され始めてい る腸内細菌叢は, 食事やストレスなどによっても劇的に その構成が影響を受けることもよく知られている。例え ば，地中海食のような野菜・穀類を中心とした食事を日 常的に摂取しているヒトの腸内細菌叢には, 難消化性多 糖を分解できる Prevotella 属や Lachnospira 属が豊富に 存在していることが明らかとなり, その代謝物である短 鎖脂肪酸も生体内に高濃度で存在することが示された ${ }^{21)}$ 。 一方, 動物性食品を中心とした食事を摂取するヒトの腸 内細菌叢は, Ruminococcus 属や連鎖球菌などが増加し ていることが示され, 腸内細菌代謝物の一つで心血管疾 患の原因となる $\mathrm{TMAO}$ (トリメチルアミン -N-オキシド) が高濃度で検出された ${ }^{22)}$ (Fig. 2)。さらに，このような 腸内細菌叢の構成変化は短時間で劇的に変化することも 明らかになっている。健常者に対し, 動物性食品あるい は植物性食品を 5 日間, 摂取し続けることで動物性食品 摂取群では胆汁酸耐性を示す 22 種類もの菌種 (Alistipes 属, Bilophila 属や Bacteroides 属など）が増加した一方 で, 植物性食品摂取群では食物繊維を分解するような菌 種（Roseburia 属や Eubacterium rectaleなど）が増加 した ${ }^{23)}$ 。また, 食事中の脂質組成の違いが腸内細菌叢 の変化に寄与し, 肥満やインスリン抵抗性の惹起に寄与 するとの報告も為された。多価不飽和脂肪酸の豊富な魚 油を摂取させたマウスにおいては, Akkermansia属, Lactobacillus 属や Bifidobacterium 属などが増加した。 一方, 飽和脂肪酸の豊富なラード摂取群には Bilophila 属や Bacteroides 属の増加に伴う血中エンドトキシン濃

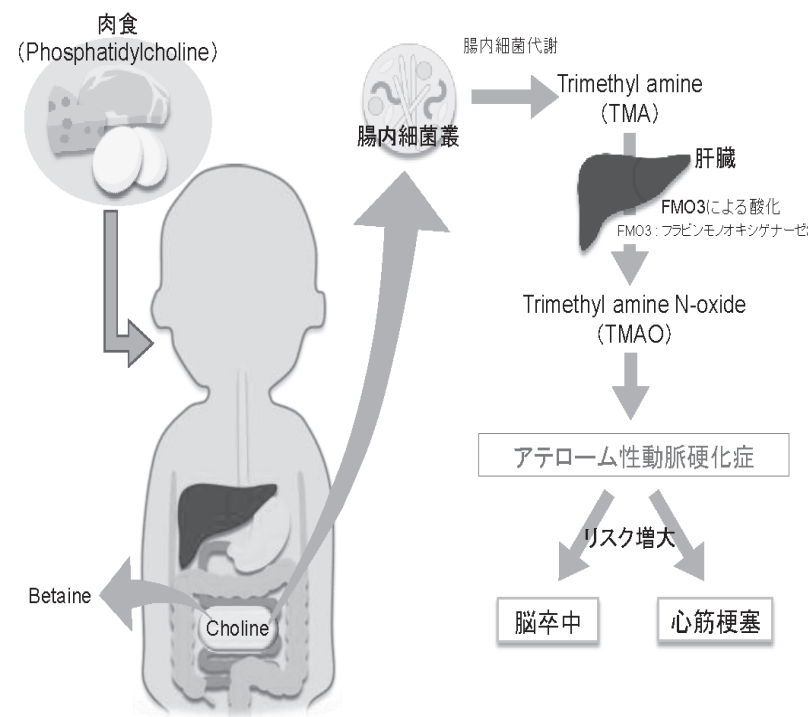

Fig. 2 腸内細菌叢と食事による疾患への影響 


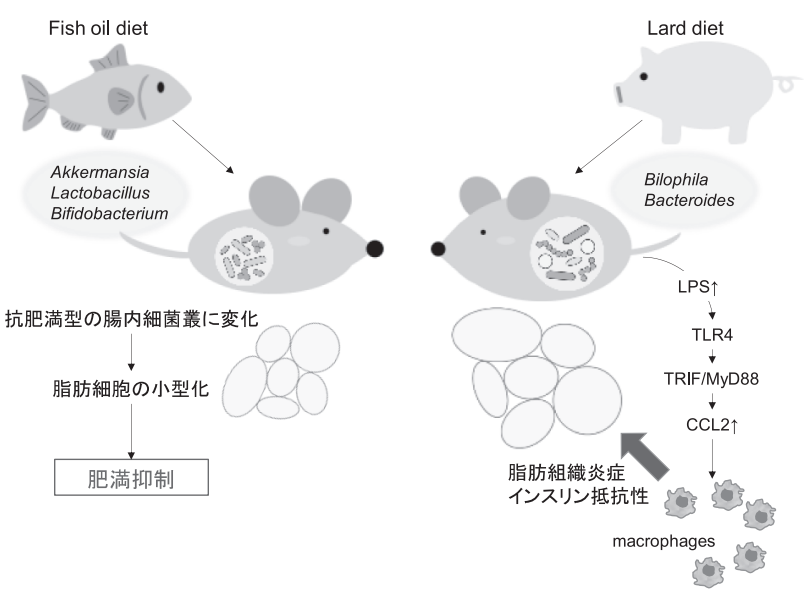

Fig. 3 腸内細菌叢と食事脂質

度の上昇と, 脂肪組織炎症やインスリン抵抗性が観察さ れた ${ }^{24)}$ (Fig. 3)。すなわち，我々と共生関係にある腸内 細菌叢は，摂取した食事の種類によってその構成を劇的 に変え, 腸内細菌代謝物の代謝パターンを制御すること で, 宿主の生体恒常性維持に関与する可能性が示唆され た。近年では, このような食事脂質や食物繊維などの栄 養成分に対する腸内細菌依存的な代謝経路が同定され， 宿主の生体調節作用に寄与する実質的な分子実体として の腸内細菌代謝物研究に注目が集まりつつある。

\section{4 腸内細菌由来脂肪酸代謝物の生体恒常性維持}

食事脂質中の主な構成脂肪酸の一つであるリノール酸 は, 我々の生命を維持するために重要な必須脂肪酸であ り，アラキドン酸カスケードを介した脂質メディエータ の産生に重要であるが, 過剩なリノール酸摂取は炎症や アレルギーの発症・増悪に寄与することも知られてい る。このような多価不飽和脂肪酸は, 腸内細菌依存的に 水酸化脂肪酸やオキソ脂肪酸などへ代謝されることが明 らかとなり，その宿主に対する生体調節作用の解明が期 待されている ${ }^{25)}$ 。例えば, リノール酸の初期代謝物で, 水酸化脂肪酸の 10-hydroxy-cis-12-octadecenoic acid （HYA）が株化細胞・マウスレベルで腸管上皮バリア機 能の一つであるタイトジャンクションの制御に寄与する ことが示されている。また，その分子メカニズムの少な くとも一つに，長鎖脂肪酸受容体を介したMAPK 経路 の活性化や，それに伴う TNF 受容体発現の制御が関与. することも示されており, タイトジャンクション損傷に 関連する炎症性疾患の予防・軽減に寄与することが期待 される ${ }^{26)}$ 。実際に，アトピー性皮膚炎改善作用 ${ }^{27)}$ や腸 管免疫制御 ${ }^{28)}$ などがマウスレベルで確認されており, 食事脂質と腸内細菌の相互作用によって，炎症性疾患を 含めた生体恒常性維持に腸内細菌代謝物の存在が重要で あることが期待される (Fig. 4)。最近では, 腸管以外の

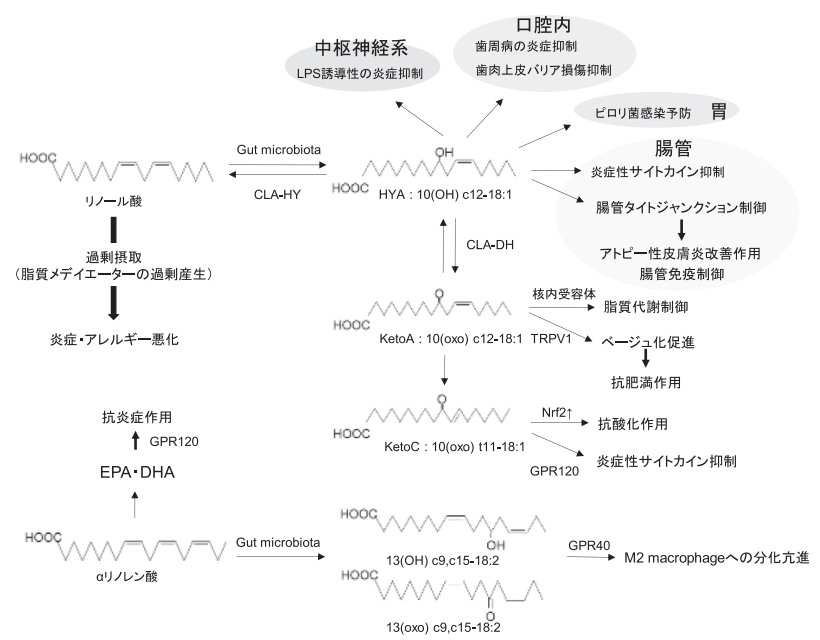

Fig. 4 食事脂質由来腸内細菌代謝物と宿主生体恒常性維持

組織においても HYA による抗炎症作用が報告されてい る。例えば, HYAがメナキノン生合成を阻害すること で胃におけるピロリ感染を予防すること ${ }^{29)}$ ，また，口 腔内においても, HYA が脂肪酸受容体を介して歯周病 原性細菌による歯肉上皮バリア損傷と歯周病における炎 症反応の抑制に寄与することが示唆された ${ }^{30)}$ 。さらに, 中枢神経系のミクログリア細胞におけるLPS 誘導性の 炎症応答を HYA が抑制することも示されている ${ }^{31)}$ 。他 にも，HYA と同様にリノール酸代謝物であるオキソ脂 肪酸の 10-oxo-cis-12-octadecenoic acid（KetoA）は核内 受容体を介した脂質代謝制御 ${ }^{32}$ や， TRPV1（カプサイ シン受容体の一つ）を介した白色脂肪組織のベージュ化 による抗肥満作用に寄与すること ${ }^{33)}$, さらに, 10-oxotrans-11-ocatadecenoic acid（KetoC）にはNrf2 活性を 介した抗酸化作用なども見出されている ${ }^{34)}$ 。非常に興 味深いことに，これら代謝物の作用は前駆体である食事 脂質中のリノール酸よりも強力であることが見出されて おり, 腸内細菌によるリノール酸代謝が宿主の生体恒常 性維持に関与していることを示唆している（Fig. 4）。腸 内細菌による不飽和脂肪酸代謝はリノール酸に限らず, 食事脂質に含まれる $\alpha$-リノレン酸, $\gamma$-リノレン酸, ア ラキドン酸や EPA などに対しても, 多様な腸内細菌代 謝物の存在が明らかとなっている。最近, $\alpha$-リノレン 酸代謝物である 13-hydroxy-cis-9, cis-15-octadecadienoic acid や 13-oxo-cis-9, cis-15-octadecadienoic acid が, 脂肪 酸受容体を介して M2 マクロファージ分化の克進に寄与 することや ${ }^{35}$ ），腸管ホルモンの一種である CCK（cholecystokinin）の分泌に寄与することが明らかにされてい $\Xi^{36)}$ 。これら腸内細菌代謝物の生体調節作用は未だ不 明瞭な部分が数多く残されているが, リノール酸代謝物 と同様, 食事脂質一腸内細菌－宿主の相互連関による宿 主の生体恒常性維持に重要な役割を果たす可能性が期待 


\section{される (Fig. 4)。}

食事脂質中の長鎖脂肪酸やその腸内細菌代謝物の生体 調節作用を明らかにする上で重要となるのが, 細胞膜上 の七回膜貫通型受容体 (GPCRs) である。長鎖脂肪酸 をリガンドとする GPCRs には GPR40 と GPR120 が知 られており，その生理機能の解明が積極的に行われてい る ${ }^{37)}$ 。例えば, GPR40 は飽和・不飽和脂肪酸の両方で 活性化され, 生体内においては脺 $\beta$ 細胞に最も発現し ていることが知られており, 直接的なグルコース誘導性 インスリン分泌に寄与することから，エネルギー代謝疾 患に対する創薬応用も行われている ${ }^{38)}$ 。また, GLP-1 や GIP なとのインクレチン分泌に寄与する腸管の L 細 胞や $\mathrm{K}$ 細胞にも GPR40の発現が確認されており, イン クレチン分泌を介した間接的なインスリン分泌を制御し ていることも予想される ${ }^{39)}$ 。近年では, 単球や好中球 などの免疫細胞に発現したGPR40に対して, STAT6 の活性化に伴う M2 マクロファージへの分化充進 ${ }^{35)}$ や Racの活性化を介した接触皮膚炎などのアレルギー性応 答を制御 ${ }^{40)}$ することも明らかにされている。一方, GPR120 は GPR40 と同様に長鎖脂肪酸をリガンドとし, その親和性は類似する一方で, GPR40 とのアミノ酸相 同性はわずか $10 \%$ 程度であることからも，GPR120 は GPR40 とは異なる生体調節作用に寄与することが推察 される。実際に, GPR120 もL 細胞に発現し GLP-1 分 泌に寄与するが, 特にマクロファージや白色脂肪組織に 高発現することが知られている。従来, 魚油に含まれる DHA や EPAの抗炎症作用はよく知られていたが, そ の分子メカニズムは明らかとされていなかった。マクロ ファージにおける TNF- $\alpha$ やLPS の誘導した細胞質内の TAK1-TAB1 複合体を介した NF- $\mathrm{KB}$ 経路・JNK 経路の 炎症促進シグナルを, $\omega 3$ 多価不飽和脂肪酸による GPR120 の活性化が $\beta$-arrestin2 を介して抑制すること が見出されている ${ }^{41)}$ 。また, GPR120の選択的なアゴニ ストが, 肥満マウスにおける脂肪組織の炎症性マクロ ファージに対して抗炎症性作用を示し, 耐糖能やインス リン感受性の改善に寄与することも示された ${ }^{42)}$ 。さらに, マウス・ヒトの両方において, 白色脂肪組織における GPR120 の機能不全が脂肪細胞の分化と脂肪酸合成の減 少を引き起こし, 肝臓での脂質合成と取り込みの立進に 伴う肥満を誘発する結果, 耐糖能低下や脂肪肝を引き起 こすことも示されている ${ }^{43)}$ 。これら長鎖脂肪酸受容体は, 免疫系疾患や代謝異常疾患などの創薬標的としてょり詳 細な生理機能の解明を行うことが, 栄養素だけでなくシ グナル分子としての長鎖脂肪酸の役割と, 生体恒常性維 持の分子メカニズムの解明に寄与すると考えられる。

\section{5 おわりに}

腸内細菌が菌体自身やその代謝物を介して宿主の生体 恒常性維持に密接に関与することが明らかとなり, 腸内 細菌叢代謝物産生に大きく影響を及ぼす「食」の重要 性が再認識されつつある。近年は, 中鎖脂肪酸・ケトン 食のような, エネルギー代謝に寄与する分子実体の合成 を生体内で誘導することにより, 代謝機能改善を促す食 事も注目を集めている。古くから知られている医食同源 の概念のように, 腸内細菌が宿主にとって有益な代謝を 行うように促すための食事の質と腸内環境を維持するこ とが, 健康であるためには重要である。特に代謝物研究 においては, 代謝物そのものを精製して与える方法, 代 謝物の原料を与える方法, あるいはプロバイオティクス のような代謝物を生体内で効率よく産生させる方法など が模索されており, 新たな機能性食品の創出の可能性が 期待される。また, これら代謝物が宿主の生体恒常性を 維持するために重要な因子であることからも, 腸内環境 の網羅的な解析が, 我々の健康増進を手助けする新規な 治療法の開発に繋がると期待される。

\section{文 献}

1) C. L. Gentile and T. L. Weir, Science 362, 776-780 (2018).

2) R. E. Ley, P. J. Turnbaugh, S. Klein, et al. Nature 444, 1022-1023 (2006).

3) P. J. Turnbaugh, R. E. Ley, M. A. Mahowald, et al. Nature 444, 1027-1031 (2008).

4) M. Rosenbaum, R. Knight, R. L. Leibel, Trends Endocrinol. Metab. 26, 493-501 (2015).

5) F. H. Karlsson, V. Tremaroli, I. Nookaew, et al. Nature 498, 99-103 (2013).

6) J. Qin, Y. Li, Z, Cai, et al. Nature 490, 55-60 (2012).

7) M. Vijay-Kumar, J. D. Aitken, F. A. Carvalho, et al. Science 328, 228-231 (2010).

8) M. Fulde, F. Sommer, B. Chassaing, et al. Nature 560, 489-493 (2018).

9) A. Everard, C. Belzer, L. Geurts, et al. Proc. Natl. Acad. Sci. US A 110, 9066-9071 (2013).

10) H. Plovier, A. Everard, C. Druart, et al. Nat. Med. 23, 107-113 (2017).

11) M. Bodogai, J. O'Connell, K. Kim K, et al. Sci. Transl. Med. 10, eaat4271 (2018).

12) C. B. Newgard, J. An, J. R. Bain, et al. Cell Metab. 9, 311-326 (2009).

13) H. K. Pedersen, V. Gudmundsdottir, H. B. Nielsen, et al. Nature 535, 376-381 (2016).

14) P. Kovatcheva-Datchary, A. Nilsson, R. Akrami, et al. Cell Metab. 22, 971-982 (2015).

15) L. Laurans, N. Venteclef, Y. Haddad, et al. Nat. Med. 24, 1113-1120 (2018). 
16) A. Koh, A. Molinaro, M. Ståhlman, et al. Cell 175, 947961 (2018).

17) A. Vrieze, C. Out, S. Fuentes, J. Hepatol. 60, 824-831 (2014).

18) I. Cho I, S. Yamanishi, L. Cox, et al. Nature 488, 621626 (2012).

19) A. Zarrinpar, A. Chaix, Z. Z. Xu, et al. Nat. Commun. 9, 2872 (2018).

20) S. Leclercq, F. M. Mian, A. M. Stanisz, et al. Nat. Commun. 8, 15062 (2017).

21) F. De Filippis, N. Pellegrini, L. Vannini, et al. Gut 65, 1812-1821 (2016).

22) R. A. Koeth, Z. Wang, B. S. Levison, et al. Nat Med. 19, 576-585 (2013)

23) L. A. David, C. F. Maurice, R. N. Carmody, et al. Nature 505, 559-563 (2014).

24) R. Caesar, V. Tremaroli, P. Kovatcheva-Datchary, et al. Cell Metab. 22, 658-668 (2015).

25) S. Kishino, M. Takeuchi, S. B. Park, et al. Proc. Natl. Acad. Sci. US A 110, 17808-17813 (2013).

26) J. Miyamoto, T. Mizukure, S. B. Park, et al. J. Biol. Chem. 290, 2902-2918 (2015).

27) H. Kaikiri, J. Miyamoto, T. Kawakami, et al. Int. J. Food Sci. Nutr. 68, 941-951 (2017).

28) P. Bergamo, D. Luongo, J. Miyamoto, et al. J. Funct. Foods 11, 192-202 (2014).

29) H. Matsui, T. Takahashi, S. Y. Murayama, et al. Helicobacter 22, e12430 (2017).
30) M. Yamada, N. Takahashi, Y. Matsuda, et al. Sci. Rep. 8, 9008 (2018).

31) S. Ikeguchi, Y. Izumi, N. Kitamura, et al. J. Pharmacol. Sci. 138, 9-15 (2018).

32) T. Goto, Y. I. Kim, T. Furuzono, et al. Biochem. Biophys. Res. Commun. 459, 597-603 (2015).

33) M. Kim, T. Furuzono, K. Yamakuni, et al. FASEB J. 31, 5036-5048 (2017).

34) H. Furumoto, T. Nanthirudjanar, T. Kume T, et al. Toxicol. Appl. Pharmacol. 296, 1-9 (2016).

35) R. Ohue-Kitano, Y. Yasuoka, T. Goto, et al. FASEB J. 32, 304-318 (2018)

36) T. Hira, S. Ogasawara, A. Yahagi, et al. Mol. Nutr. Food Res. 62, e1800146 (2018).

37) J. Miyamoto, S. Hasegawa, M. Kasubuchi, et al. Int. J. Mol. Sci. 17, 450 (2016).

38) Y. Itoh, Y. Kawamata, M. Harada, et al. Nature 422, 173-176 (2003).

39) S. Edfalk, P. Steneberg, H. Edlund, Diabetes 57, 22802287 (2008).

40) T. Nagatake, Y. Shiogama, A. Inoue, et al. J. Allergy Clin. Immunol. 142, 470-484 (2018).

41) D. Y. Oh, S. Talukdar, E. J. Bae, et al. Cell 142, 687-698 (2010).

42) D. Y. Oh, E. Walenta, T. E. Akiyama, et al. Nat. Med. 20, 942-947 (2014).

43) A. Ichimura, A. Hirasawa, O. Poulain-Godefroy, et al. Nature 483, 350-354 (2012). 